\title{
PAURĀNIC INFLUENCE ON THE ASSAMESE FOLK SONGS
}

\author{
Dr. Jewti Boruah
}

\begin{abstract}
The purānas have great influence on the society and culture of Assam along with the other Indian cultures. An immense numbers of folk literature and traditions of different tribes and races of Assam enrich the Assamese culture. Many folk songs are sung by the people of Assam in various occasions. These songs are greatly influenced by the events of different ages. Hence, the influences of purānas are also observed in these songs. In this paper, an attempt will be made to highlight the Paurānic influence on the Assamese folk songs through some references.
\end{abstract}

The purānas are considered as the sources of knowledge. They have great influence on Indian society and culture through the ages. This influence of purānas also extends to the society and culture of Assam along with the other Indian cultures. It is well known that Assam is a land of many races and tribes. Therefore there are a large number of cultural elements present in the heart of Assam. The Assamese culture contains immense number of folk literature and traditions. The traditional beliefs, superstitions, myths, customs, tales, and practices etc. of the people of this land vary from tribe to tribe, community to community. This may be different but all of them contribute for the enrichment of the Assamese society and culture. Like any other region of the country some folksongs are traditionally sung by the people of Assam and they occupy a peculiar position in the Assamese culture. Here are various types of folk songs in the storehouse of Assamese culture like Bihunām, Huncari, Bìānām, Dhāinām, Āinām, Bāramāhī Gīt, Bongīt, Nāonkhelor Gìt, Garakhiyā Gìt, Dehbicārar Gìt, Ṭokārī Gīt, Kāmrūpī Lokagìt, Goalparia Lokagìt, Maho-ho Gït ...etc. These songs are the expression of common beliefs, traditions, myth and legends, joys and sorrows, hopes and despondencies, feeling of love and separation of the Assamese folk. Therefore, these are the 
invaluable resources of Assamese culture and penetrated into the heart of the Assamese people. It is difficult to state as to when the Assamese folksongs were circulated first. But these songs are greatly influenced by the events of different ages. In the context of Paurānic Influence on the Assamese folksongs, here, we have made an attempt to glimpse into certain types of songs only, as it is not possible to cover all the folksongs of great Assam.

- Bihunām : In the month of Bohāg (Vaiśākha, April-May), the people of Assam celebrate Rangālïbihu with great pomp. During the festival, the boys and girls perform bihu dance and huncari accompanied with songs which are called bihunām. In some of these songs we get reference of Paurānic god and goddess. For instance-

prathame pranāmo $\bar{a} i$ sarasvatī dvitīya pranāmo haril trịtiya praṇāmo gānvar bự̂ā methā dhari jāon nāmare guri/ / ${ }^{1}$

Here, it is stated that before starting the bihunām, the bihu performer salutes the goddess Sarasvatī, Viṣnu and the elders of the village. Again, Brahmā and Viṣnu are mentioned as-

brahmāi sarajā nāmare kathiyā viṣnuye sarajā nām/ beyā nām olāle sarvadoṣ khemibo bihure gïtake gām $/ /^{2}$...etc.

One example of huncari nām is-

krșṇāir murate bakul phul epāhi niyar pāi mukali hal ai govindāi rām/ ${ }^{3}$...etc.

- Biyānām- Biyānām is a kind of folk song of Assam. Biyānāms are sung in the marriage ceremony by the folk women. These are sung with a melodious tune indicating different functional context of the ceremony from the beginning to the end. In these biyānāms, the influences of mythical and legendary accounts of the purāns are observed. In the marriage ceremony, the bridegroom and bride are considered as Śiva and Pārvatī or Ūṣā and Aniruddha or Kṛ̣ṇa and Rukmin̄ī or Rāma and Sītā. Similarly, the father of the bridegroom is considered as Daśaratha while mother considered as Kauśalyā or Daivakī. Sometimes, the father of the bride is considered as Dakșarāja. In the marriage songs, it is found that the mythical marriage accounts of these paurānic characters are drawn to the 
comparison with the common bridegroom and bride. There are many examples in this regard. Some of them as-

mārār alam̄kār thovā kati kari deutārār alamikār thovā he/ rāme di pathāise suvarṇa alamikār hāte jore kari lovā he/ / ${ }^{4}$...etc.

śiva gonsāi āhise dambaru bājise dakṣarajār sotālat kanyā bhikṣā māgise $/ /^{5}$...etc.

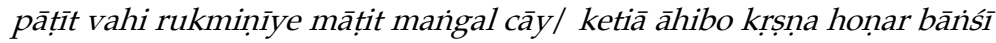
bāy $/ /^{6}$...etc.

- Dhāinām - These songs are called nicukaṇi gït also. The Assamese mother used to sing these songs to make her child sleepy. The reference of Kṛnna is found in the midst of these type of song to jaṣodā māu mathani thovā/ kṛṣnai kāndise kolāt lovāa/ / ${ }^{7}$...etc.

- Brndāvanì nām - The theme of these songs is the various sportive activities of Lord Śrīkṛnna performed in the Vṛndāvana. Generally, these songs are sung in the religious functions like Gopinī savāha by the followers of Vaișnavism of Assam.

vrndāvanar māje prabhu āsilā lukāy/bhāleto gopinī kānde visāri nāpāy $/ /^{8}$... etc.

Here, Kṛṇa's sport with the gopīs or the female cowherds is revealed.

- Dehvicārar git - These songs are simple expressions of philosophical and spiritual aspects. The main theme of these songs is the non-eternal human body and the eternity of soul. It is reflected in these songs that people can not realize the Supreme Being due to their ignorance as their minds are covered with kāma, krodha, lobha, moha etc. Therefore, they run after the worldly pleasure and get trouble in this life. These songs also explicit the influence of paurānic literature -

brahmā harihara krșṇa balobhadra ātmār bhitare ase/ganigā gayā kāśī gandakī jamunā āse śarīror kāje/ / ...

dehar karun prān bāndhava dehār bisār karun/caidhyaya baikuntha caidhyaya brahmāṇ̣̂a dehāte bisār dharun $/ /^{9}$... etc.

- Tokārīgit - These songs bear similarity to the Dehbicārar gitt. These are mainly related to spiritual devotion and philosophical 
aspects. These songs are usually sung by a group with tokārī (a folk musical instrument of Assam, having a single string and played with a finger. It is found that the names of Siva and Pārvatī are associated with this songs.

jetiā birikhe dui pāt melile talaloi melile śiyāl hei gachejupi khoje mahādeve tokārī hājongoi diyā/ mahādev gosānye tokārì hājise bāte pārvatī guṇā// $/{ }^{10} \ldots$ etc.

Here, it is stated that Śiva made tokārī and Pārvatī made its string.

- Bāramāhī gït-There are descriptions of the twelve lunar months in these songs. The main theme of this type of songs is the separation of the lovers and their mental conditions in such stage as well as the natural changes of the months. These songs are classified as Rām Bāramāhī, Sītā Bāramāhī, Śānti Bāramāhī, Rādhā Bāramāhì... etc. In these songs the love and separation and mental conditions of Rāma and Sītā, Rādhā and Krṣna are stated.

\section{Example of Rām Bāramāhī-}

āghoṇa māhote rāme mane kare cintā/ kimate vañciba āmi sange loiyā sìtā// ... etc.

āge goilā prabhu rām pāchata lakșmaṇa/ kātir śuklā pakṣe sītā harilā rāvanal / ${ }^{11}$...etc.

\section{Example of Rādhā Bāramāhī-}

ohe kṛ̦ṇa,bahāgar māhate rādhe deutār garjani/deutār garjani śuni matsye dei ujani $/ /{ }^{12}$...etc.

Example of Sītā Bāramāhī-

āghonar māhate bāpu śārile bātar/ dūrar parā rāmacandrak karisu kātar// puhare māhate bāpu ati bor śît/mai abhāginī sītār nāi thānthit $/ /{ }^{13}$...etc.

- $\bar{A} \boldsymbol{i}$ nām-These songs are the result of folk belief. The Assamese folk believe that mums, chicken pox etc. are the $\bar{a} i$ or goddess Mahāmāyā Bhagavatī (a form of goddess Dūrgā). Therefore, when someone suffers in these diseases some lyrical prayers are recited by the women folk to satisfy goddess Mahāmāyā. Many ài-nāms are found which exposes the magnanimity of goddess 
Mahāmāyā. Some songs are connected with the name of Śiva and Pārvatī. According to folk belief $\bar{a} i$ lives in Kailāsa with Mahādeva. One of such songs is furnished in reference of it.

āi āhibor hol bahudin mahādeu pathāise khedā/jovāne nojovā āi bhagavatī kailāśs hoise śudāa / $/{ }^{14}$... etc

- Nāonkhelor git - These folk songs are sung by the boat men. In the river ways, one of the important means of transport is boat. To drive a boat, it requires hard labour. So, to minimize their labour and tiredness the boatmen sing such type of songs. The theme of some songs is the love sport of Rādhā and Krșna. It shows that these songs also bear the paurānic influence in them.

kānāi pār karā re,belir dike cābā/nașta gaila dudher bhāṇ̣̂ār bajā goilā bayāal/ / ${ }^{15}$...etc.

Here, Rādhā requests Kṛṣna to pass herself from one side of the river to the other by his boat.

From the above discussion, it is observed that the common people of Assam are greatly influence by the paurānic literature. Actually Assam has a rich record of study and practice of different branches of knowledge including purānas .Assam is a producing ground of various śāstras like Kālikāpurāna, Yoginītantra, Haragaurīsaminvāda... etc. Moreover, many great scholars of Assam have been offering their contribution to the ocean of Sanskrit literature. Of course, the Assamese folk songs are not directly influenced by the original purānas which are in Sanskrit as this language is not communicative or popular among the common people of this land. On the other hand, the folk songs are come out from the mouth of the simple folk.

The purānas mainly advocate the worship of a particular deity from the Hindu trinity- Brahmā, Viṣnu and Maheśvara or Śiva. These three main gods are mentioned abundantly in the Assamese folk songs along with the legends and activities related with them. It is also noticed that among the trinity, Viṣnu or Hari or Krṣna is mentioned most. We can consider the Neo-Vaișnavism movement propagated by Śankardeva in Assam as a reason of it. This ism is mainly based on Śrimadbhāgavatapurāṇa and Gītā. For extending Neo-Vaiṣnavism, Śankardeva introduced the Satra institutions, Nāmghar, composed many religious books, songs, dramas, poems 
and also translated some Sanskrit saāstras into local language keeping the simple folk of Assam in his mind. Thus, his great contributions and other followers of Vaisnavism enriched the storehouse of Assamese culture and helped the society of Assam to get influenced by the knowledge of different śāstras. Therefore, we find the Paurānic Influence in the midst of the Assamese folk songs too.

\section{Endnotes:}

1. Bihugīt āru Banghoșā, p.2

2. Ibid., p.2

3. Asamiyā Lokasāhityar Rūprekhā, p.106

4. Ibid., p.144

5. Ibid., p.149

6. Ibid., p.204

7. Oral sources

8. Asamiyā Lokasāhityar Rūprekhā, p.109

9. Ibid., p.73

10. Ibid., p.68

11. Ibid., p.122

12. Ibid., p.122

13. Ibid., p.121

14. Ibid., p.86

15. Ibid., p.99

\section{BIBLIOGRAPHY}

- Bezbora, Dr. Nirajana : Lokattatva Jijyansa, Banalata, Dibrugarh-1

- Bharali, Arunima : Assamese Culture as Reflected in the Mediaeval Assamese Literature, Lawyers Book Stall, Panbazar, Guwahati-1,1999

- Bharali, Songita (ed.) : Asamiyā Lokagīt Samigrah, Assam Book Trust, 2013

- Borua, Dr. Birinci Kumar : Asamar Loka Sanskriti, Bina Library, Guwahati-1, 2002

- Das, Surendra Kumar : Biṣnu Purāna (Assamese Translation), Banalata, Panbazar, Guwahati-1, $2^{\text {nd }}$ edn., 2014 
- Gogoi, Dr. Lila : Asamiya Lokasāhityar Rūprekhā, Banalata, Dibrugarh-1,2007

- Gogoi, Dr. Lila : Bihugit āru Banghoșā, Banalata, Dibrugarh-1, 2007

- Goswami, Dr. Malinee ( ed.) : Bhagavatbhāvārthadīpikā, Publication Board Assam, Guwahati-21, Assam, $1^{\text {st }}$ edn., 2005

- Mahanta, Pradipjyoti (ed.) : Śrimmanta Śamkardeva : Samāj āru Samiskriti, Puberun Prakash, Guwahati-1,2002

- Majumder, Dr. Bimal : Purānarar Paricay, Chandra Prakash, Guwahati-1, $1^{\text {st }}$ edn., 2002

- Thakuriya, Chakiram : Otharapurān - Bhaktikathā, Banalata, Panbazar, Guwahati-1, 2016 